\title{
Study on Reading Strategies of Business English based on Training Experiment
}

\author{
Liyuan Liü, a \\ ${ }^{1}$ Jilin Agricultural Science and Technology University, 132101, Jilin City, China. \\ aliyuan-liu@126.com
}

Keywords: Business English teaching, reading strategies, training experiment.

\begin{abstract}
In the process of Business English teaching, there exists ambiguity of purpose of the reading with much importance attached, whereas the process of reading is neglected. Actually, the purpose of Business English reading should be inseparable with the content, discourse and skills of businesses. In this paper, the strategies were generated by the research for the Business English-majored students; and helps targeting the aim of the reading and forming effective strategies in Business English reading; and helps improve the effectiveness of study and awareness of employment to reading strategies to make Business English teaching and employment of the strategies complimentary.
\end{abstract}

\section{Introduction}

English Teaching in the 21st century is facing great challenges and how its being extracted at the National Western Development Strategy Seminar for English Majors report said: "The changes in the new century, facing Western main features: first, social the demand for English talent showing a trend of diversification, foreign language colleges single training goal presents a challenge in the past that a single English professional basis and skilled personnel can not meet the market economy; second, middle school English teaching raise the level of the rapid development of college English teaching level, as well as the majority of students thirst for knowledge of English and English skills, to teaching English major Western institutions a higher level of requirements. In order to develop complex professional English talent, many experts and scholars to deal with college English teaching of appropriate adjustments, such as Zhang Bryan said: "Points (College English Teaching Reform) is under the general English teaching task into secondary schools to completion, so that students enter college can focus on learning English ; Runqing pointed out:" the future of English teaching is more and more integrated with one aspect, the ESP will be teaching English Teaching in the 21st century mainstream, with our new students into the university to improve the overall level of English, English for Specific purposes teaching will become the development direction of college English teaching. conform to this trend, China's current foreign language teaching universities are engaged in a major adjustment, implementation ESP teaching has been included in the agenda of many schools.

"Foreign experiments proved that when foreign language teaching and teaching combine the efficiency of learning a foreign language than in isolation, purely high way to learn a language, because only students through their own personal use of language to implement real communication behavior, in order to make at the same time their language learning to produce good practical effect. " (5) recent years, some universities, such as Guangdong University of Foreign Studies and other schools, foreign language teaching and teaching aspects of combining a useful attempt, is to improve students' professional level improve English application and practical ability to achieve professional teaching English plus will become one of the tendency of College English Teaching reform.

\section{The importance of Business English Reading}

General English and Business English are very different, "Business English itself interdisciplinary complexity of culture is' English + X 'complex talent", "Professional Business English is" English + professional', so our country, a complete business English major, should pay attention to both 
language and skills, but also to the business professional content, two elements are indispensable "Ellis \& Johnson (1994) the English speaking business English learners are divided into two categories: professional business students and have some work experience students. Rely on background knowledge, they will not substantially absorb business knowledge while learning English as a business purpose, so the focus of foreign business English study method is that the language and skills. However, Chinese students studying business English in school, usually English majors, and no work experience, so learning business English, gets also an important learning goals for business knowledge. Due to constraints locale, the teaching of reading has always played an important role in foreign language teaching, reading and learning to improve the efficiency of a direct impact on the level of students' English proficiency, as Huang Yuanshen said: "Reading in English teaching position, very concerned of, I think mastered basic grammar and sentence after the primary means to improve their English learners are reading. "(2) business English reading teaching should teach students reading skills, and guide them to increase their business knowledge in reading, and then carried out critical reading training to foster students' critical thinking skills.

The best way to learn the language from the law point of view, to improve the foreign language proficiency of the language is based on the input, linguists say that in addition to immersive native in the target language to learn, but to improve the level of foreign language a large number of widely read; but China's lack of natural teaching English language acquisition environment, primarily through reading learners master the language knowledge and get valid information, thus improving the ability to use the English language. Thus increasing the amount of reading and improve reading quality is the most important measure to make up for lack of language input. Second language learners tend to be more interested in reading, there is a certain reading habits, as long as the scientific guidance, read the effect will be very significant. Communicative approach that, in various occasions the proper use of language is the main way to master the language. A lot of reading can provide a variety of practical examples of the language used in the scene for the students, then for business English teaching is concerned, the importance of the teaching of reading becomes evident.

\section{Interview Results and Discussion}

In the final phase of the experiment, there is a choice between the students interviewed. It confirmed by the method of qualitative research training if they pass policies to improve the awareness of the policy, what problems still exist. Total interviewees clever students: higher student achievement before 5, the lower the score after five students, as well as the results of three large fluctuation amplitude students. Interview results are as follows:

In an interview we found that some students can consciously learn reading strategies and try to use these strategies in reading. Conversely, some students is not strong sense of strategy, as long as they expanded the amount of reading and more questions, the results will improve business English. Some interviewees are not interested in business English, rarely take the initiative to read, learning to cope with the exam. These students' English scores and reading levels are low, which also shows the catalytic role of motivation and interest in learning. Further Business English Reading purposeful students are more active use of reading strategies.

Improve the teaching management system, stimulate college students' learning motivation. Training for policy from students before and after comparison can be seen, where my school college students a serious lack of motivation to learn. After entering the school, the students for their future of a confused, combined with the college students, and undergraduate students have always felt a big gap, relatively strong sense of inferiority, so nothing at all interested in the natural process of learning business English will not adopt a positive attitude to the use of a variety of effective strategies, frequency of use of such tactics is not high. To fundamentally change this situation, we have to improve the teaching management system, changing the examination system so that teachers play a certain amount of flexibility, autonomy and creativity through a variety of ways to assess students. Stimulate college students interested in business English. Because "Motivation comes from a keen interest in what they have learned something." 
Interview, is showing little learning initiative visitors. Therefore, to update teaching concepts, continue to implement the "learner-centered" teaching mode. Teachers in teaching should pay special attention to the "learner-centered" concept of teaching, as much as possible to create opportunities for students to participate in teaching activities, we should always pay attention to students' progress, and timely recognition, appreciation use education, establish their learning confidence. The only way to enable students to truly become the masters of learning, then actively choose their own learning strategies to improve self-learning ability to improve learning efficiency, has gradually become a social adaptation autonomous learners.

Business English students in the reading process, there are some common issues that hinder the improvement of their reading ability, the reason is mainly the following points: 1 . Language weak foundation. Mainly that there is insufficient vocabulary and not read long complex sentences. 2. develop a poor reading habits. The typical diet is as follows: whispered reading, silent reading, word for word reading, which greatly affect improve your reading speed. 3. Low reading comprehension. Many of the students will focus on a particular language points, ignoring the full text of the framework structure. 4. Lack of relevant expertise. Some articles appearing in professional terms often become students to read during the stumbling block. 5. unfamiliar language documents. Students of many business articles to cite legal provisions, business contracts and other terms of difficulty in understanding, slow reading speed. In short, the reading strategies, knowledge of the language barriers and obstacles content icon.

In an interview with the author the use of "sound thinking" approach to understand the different reading levels of students' reading process and application strategy, focusing on four key reading strategies: prediction, skimming, scanning reading, reasoning and the use of resource policy were survey.

1. Prediction: this is the use of more land policy, high scores can be predicted based on the context, but the use is not flexible enough, for example, do not realize the relationship between the title and content of the article, we do not proceed from a special business English style structure prediction . Overall, the high and low scorers on the use of this strategy was not very good. The reason is that not verify his guess, few predict the joy of success, thus affecting the next generation of prediction.

2. Skimming and seek read: high and low scores are more to use these two strategies. Interviewers are more emphasis on finding the topic sentence of the paragraph, in order to understand the text; also attached great importance to the beginning and end of the article.

3. Reasoning: high scorers greater use of this strategy. They have more background knowledge, they are able to use a variety of channels to understand the relevant knowledge, scorers lack background knowledge makes their guess little success. Highest scores in the reading process can be obtained by the information content of the article, and can use existing knowledge to judge the reasoning, it is efficient reading mode is "Interaction reading" mode.

4. Resource Strategy: Almost all of the interviewees have recognized the reading process for resource policies greatly increased their motivation to learn and interest, and to some extent on the rich business knowledge, achieved one of the purposes of business English reading; However, the high and low scores are also differences, high scores and grades increase by a big margin reported them to take the initiative to read in class, but only in the lower scorers inform teachers and students before going to read related content .

Interview, that the individual students in the classroom under the teacher's guidance, can take the initiative to use newly learned strategy, but would not extracurricular, this is obviously a lack of learning consciousness and willpower is weak. Short-term training will not produce long-term effects on students, nor will they mold into a skilled user policy. Therefore, teachers in the usual teaching students to continue to strengthen the awareness of policy, strategy training to long-term, the long-term repeated training in order to achieve the purpose of automation.

Interviews also show that training students of different strategies different attitude, different levels of students to master the four strategies are not the same. $80 \%$ of the students to read the policy in favor of the main line of teaching methods. They believe that this training method can "make teaching achieve a multiplier effect," "can enhance students' self-confidence, a sense of students", give full 
play to the role of non-intelligence factors. Students also "want to continue in the future." But 20\% of the students choose and use reading strategies difficult; especially in the exam. Lower grades of the students that their greatest gains is the strategy of using resources, by getting more effective material, they are business English learning motivation significantly improved. Visible's corpus to improve business English reading is helpful.

\section{Conclusion}

Through quantitative and qualitative research conclusions can be drawn about: most students have a correct understanding of business English reading, a clear business purpose that is reading English language, business knowledge and skills of the synchronization acquisition; college students to use reading strategies overall situation low, after the strategy training, both for low or high packet grouping students use policy awareness has improved significantly. Independent sample test pre-test and post-test, Sig is .014, indicating that: effective training strategies dominant, significant business-related English reading proficiency and reading strategies to use exists.

Applicability Features Business English reading course, makes it a popular college English majors popular subject. But in actual teaching, basic business English reading class or follow the foundation stage English Intensive or Extensive teaching ideas a language in order to accumulate knowledge and improve reading skills-based, it does not take into account as ESP has the particularity and students through language acquisition requires business knowledge. From reading teaching English for business purposes, the needs of students in mind, discusses business English reading should be professional knowledge, reading skills, language knowledge effectively combine the three.

\section{References}

[1] Lv tongue coated remote. Chinese Students' English Reading Strategies. Educational Research, Tsinghua University, 1998, (4).

[2] Long Markov. Facing the New Century Business English teaching. Higher Education Research, 1999 (1).

[3] LIU Dan-dan Strategy reading. Chinese English learners. Foreign language, 2002, (6).

[4] Liu public law. On ESP attributes corresponding to the teaching method. Teaching of Foreign Languages, 2001, (12).

[5] Liu Yichun learning successful and unsuccessful use of English reading research policy differences. Foreign Language Teaching, 2002, (3).

[6] Lin Tian Lake. Development of Business English subjects of Xiamen University, 2001, (4).

[7]Lei Chunlin business content based language teaching [J7. International Business Studies, 2006, (6).

[8]Experimental study of Meng Yue college English reading strategies. Foreign Language Teaching, 2004, (4).

[9]Ma Guanghui difference of high and low packet grouping students in learning strategies. Western sector, 1997 (2).

[10]Business English course objectives and teaching principles. Western intellectual circles Ruan Ji University, 2005, (2). 